\title{
Novel Supramolecular Hydrogels Respond to Ligand-Receptor Interaction
}

Yan Zhang, Hongwei Gu, Zhimou Yang, Bing Xu

\section{Supporting Information}

General. Chemical reagents and solvents were used as received from commercial sources. ${ }^{1} \mathrm{HNMR}$ spectra were obtained on a $300 \mathrm{MHz}$ Varian XL-300, CD on a JASCO J-810 spectropolarimeter, emission spectra on a Perkin-Elmer LS-55 luminance spectrometer, and SEM on JOEL-6300 electron microscope.

Synthesis of Fmoc-D-Ala-D-Ala (1): N-(fluorenyl-9-methoxycarbonyl) D-Alanine (311mg, 1mmol) and $\mathrm{N}$-hydroxysuccinimide $(115 \mathrm{mg}, 1 \mathrm{mmol})$ were dissolved in $15 \mathrm{ml}$ of anhydrous dimethoxyethane. The solution was cooled to $4^{\circ} \mathrm{C}$, and dicyclohexylcarbodiimide $(227 \mathrm{mg}, 1.1 \mathrm{mmol})$ was added to the solution. After stirring for $24 \mathrm{hrs}$. at $4^{\circ} \mathrm{C}$, the urea precipitate was filtered out and the filtrate was concentrated to dryness by evaporation of the solvent. The resulted N-hydroxysuccinimide ester of Fmoc-D-Ala was collected and used in the following step without further purification. Then a solution of N-hydroxysuccinimide ester of Fmoc-D-Ala $(204 \mathrm{mg}, 0.5 \mathrm{mmol})$ in $2 \mathrm{ml}$ of acetone and $8 \mathrm{ml}$ of ethanol was added under stirring to $2 \mathrm{ml}$ of water solution containing $45 \mathrm{mg}$ of D-Alanine $(0.5 \mathrm{mmol})$ and $84 \mathrm{mg}$ of sodium bicarbonate( $1 \mathrm{mmol}$ ). After stirring for $20 \mathrm{hrs}$., the organic solvent was evaporated, additional $5 \mathrm{ml}$ of water were added, and the insoluble impurities were removed through filtration. Then the filtrate was acidified with conc. hydrochloride, and the precipitate was collected and washed several times with water. After drying in vacuo, 130mg (68\% based on Fmoc-D-Ala) of Fmoc-D-Ala-D-Ala were obtained. Similar procedure was applied to synthesize Fmoc-L-Ala-L-Ala (65\%), Fmoc-Gly-Gly (60\%), FmocGly-D-Ala (68\%), Fmoc-Gly-L-Ser (59\%), and Fmoc-Gly-L-Thr (65\%).

${ }^{1} \mathrm{HNMR}$ of $1\left(300 \mathrm{MHz}, \mathrm{DMSO}-d_{6}\right) \delta(\mathrm{ppm}): 8.21(1 \mathrm{H}, \mathrm{d}, 7.2 \mathrm{~Hz}), 7.99(2 \mathrm{H}, \mathrm{d}, 7.2 \mathrm{~Hz}), 7.83(2 \mathrm{H}, \mathrm{t}$, $6.6 \mathrm{~Hz}), 7.59(1 \mathrm{H}, \mathrm{d}, 7.8 \mathrm{~Hz}), 7.52(2 \mathrm{H}, \mathrm{t}, 7.2 \mathrm{~Hz}), 7.43(2 \mathrm{H}, \mathrm{td}, 7.2 \mathrm{~Hz}, 0.6 \mathrm{~Hz}), 4.34(4 \mathrm{H}, \mathrm{m}), 4.18(1 \mathrm{H}$, $\mathrm{m}), 1.34(6 \mathrm{H}, \mathrm{dd}, 7.2 \mathrm{~Hz})$. MS: calc. $\mathrm{M}^{+}=382$, obsvd. $(\mathrm{M}+1)^{+}=383$.

${ }^{1} \mathrm{HNMR}$ of $2\left(300 \mathrm{MHz}, \mathrm{DMSO}-d_{6}\right) \delta(\mathrm{ppm}): 8.22(1 \mathrm{H}, \mathrm{d}, 7.2 \mathrm{~Hz}), 7.99(2 \mathrm{H}, \mathrm{d}, 7.2 \mathrm{~Hz}), 7.84(2 \mathrm{H}, \mathrm{t}$, 6.6Hz), $7.59(1 \mathrm{H}, \mathrm{d}, 7.8 \mathrm{~Hz}), 7.52(2 \mathrm{H}, \mathrm{t}, 7.2 \mathrm{~Hz}), 7.43(2 \mathrm{H}, \mathrm{td}, 7.2 \mathrm{~Hz}, 0.6 \mathrm{~Hz}), 4.34(4 \mathrm{H}, \mathrm{m}), 4.16(1 \mathrm{H}$, $\mathrm{m}), 1.34(6 \mathrm{H}, \mathrm{dd}, 7.2 \mathrm{~Hz})$. MS: calc. $\mathrm{M}^{+}=382$, obsvd. $(\mathrm{M}+1)^{+}=383$.

${ }^{1} \mathrm{HNMR}$ of 3 (300MHz, DMSO-d $\left.d_{6}\right) \delta(\mathrm{ppm}): 8.22(1 \mathrm{H}, \mathrm{t}, 5.4 \mathrm{~Hz}), 7.99(2 \mathrm{H}, \mathrm{d}, 7.2 \mathrm{~Hz}), 7.81(2 \mathrm{H}, \mathrm{t}$, $7.5 \mathrm{~Hz}), 7.67(1 \mathrm{H}, \mathrm{t}, 6.0 \mathrm{~Hz}), 7.52(2 \mathrm{H}, \mathrm{t}, 7.2 \mathrm{~Hz}), 7.43(2 \mathrm{H}, \mathrm{t}, 7.2 \mathrm{~Hz}), 4.36(3 \mathrm{H}, \mathrm{m}), 3.86(2 \mathrm{H}, \mathrm{d}, 6.0 \mathrm{~Hz})$, $3.75(2 \mathrm{H}, \mathrm{d}, 6.0 \mathrm{~Hz})$. MS: calc. $\mathrm{M}^{+}=354$, obsvd. $(\mathrm{M}+1)^{+}=355$.

${ }^{1} \mathrm{HNMR}$ of 4 (300MHz, DMSO- $\left.d_{6}\right) \delta(\mathrm{ppm}): 8.22(1 \mathrm{H}, \mathrm{d}, 7.0 \mathrm{~Hz}), 7.97(2 \mathrm{H}, \mathrm{d}, 7.2 \mathrm{~Hz}), 7.80(2 \mathrm{H}, \mathrm{d}$, 7.2Hz), $7.61(1 \mathrm{H}, \mathrm{t}, 4.8 \mathrm{~Hz}), 7.50(2 \mathrm{H}, \mathrm{t}, 7.2 \mathrm{~Hz}), 7.41(2 \mathrm{H}, \mathrm{t}, 7.2 \mathrm{~Hz}), 4.34(4 \mathrm{H}, \mathrm{m}), 3.75(2 \mathrm{H}, \mathrm{m}), 1.37$ $(3 \mathrm{H}, \mathrm{d}, 7.2 \mathrm{~Hz})$. MS: calc. $\mathrm{M}^{+}=368$, obsvd. $(\mathrm{M}+1)^{+}=369$.

${ }^{1} \mathrm{HNMR}$ of $5\left(300 \mathrm{MHz}, \mathrm{DMSO}-d_{6}\right) \delta(\mathrm{ppm}): 8.07(1 \mathrm{H}, \mathrm{d}, 7.8 \mathrm{~Hz}), 7.97(2 \mathrm{H}, \mathrm{d}, 7.2 \mathrm{~Hz}), 7.79(2 \mathrm{H}, \mathrm{d}$, $6.9 \mathrm{~Hz}), 7.63(1 \mathrm{H}, \mathrm{t}, 6.0 \mathrm{~Hz}), 7.50(2 \mathrm{H}, \mathrm{t}, 7.2 \mathrm{~Hz}), 7.40(2 \mathrm{H}, \mathrm{t}, 7.2 \mathrm{~Hz}), 4.34(4 \mathrm{H}, \mathrm{m}), 3.72(2 \mathrm{H}, \mathrm{m})$. MS: calc. $\mathrm{M}^{+}=384$, obsvd. $(\mathrm{M}+1)^{+}=385$.

${ }^{1} \mathrm{HNMR}$ of $6\left(300 \mathrm{MHz}, \mathrm{DMSO}-d_{6}\right) \delta$ (ppm): $7.97(2 \mathrm{H}, \mathrm{d}, 7.2 \mathrm{~Hz}), 7.81(3 \mathrm{H}$, overlapped), 7.69 (1H, t, $6.0 \mathrm{~Hz}), 7.50(2 \mathrm{H}, \mathrm{t}, 7.2 \mathrm{~Hz}), 7.43(2 \mathrm{H}, \mathrm{t}, 7.2 \mathrm{~Hz}), 4.34(4 \mathrm{H}, \mathrm{m}), 4.18(1 \mathrm{H}, \mathrm{m}), 1.14(3 \mathrm{H}, \mathrm{dd}, 6.6 \mathrm{~Hz})$. MS: calc. $\mathrm{M}^{+}=398$, obsvd. $(\mathrm{M}+1)^{+}=399$.

SEM sample preparation: A silicon wafer, which has been cleaned by $\mathrm{O}_{2}$ plasma, was dipped into a sample of the hydrogel, then pulled out and placed in a small glass vial. The vial containing the wafer was frozen in liquid nitrogen. The frozen sample was then kept in vacuo for at least 12 hours to completely remove water before sputtering with a thin layer of gold.

Thermal and $\mathrm{pH}$ responses of the hydrogel of 1 : 


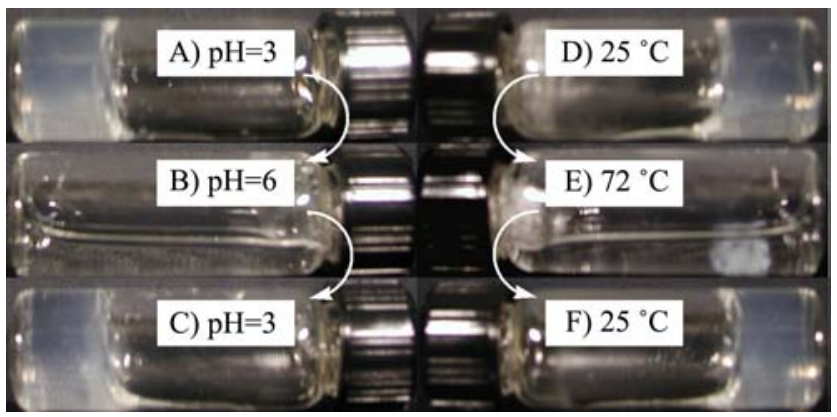

Figure 1. The phase transitions of the hydrogel of $\mathbf{1}\left([\mathbf{1}]=3.6 \mathrm{mM}\right.$ in $\left.\mathrm{H}_{2} \mathrm{O}\right)$ induced by the changes of $\mathrm{pH}(\mathrm{A}-\mathrm{C})$ and temperature (D-E).

Procedure to generate hydrogel: Fmoc-D-Ala-D-Ala $(1.9 \mathrm{mg}, 5 \mu \mathrm{mol})$ was mixed with $1.2 \mathrm{~mL}$ water, and $2 \mu \mathrm{L}$ of $1 \mathrm{M} \mathrm{NaOH}$ solution was added to the mixture to turn the suspension into a clear solution. Then the $\mathrm{pH}$ of the mixture was adjusted to 3 carefully to afford the hydrogel immediately. Other hydrogels listed in the table were also obtained using similar procedures.

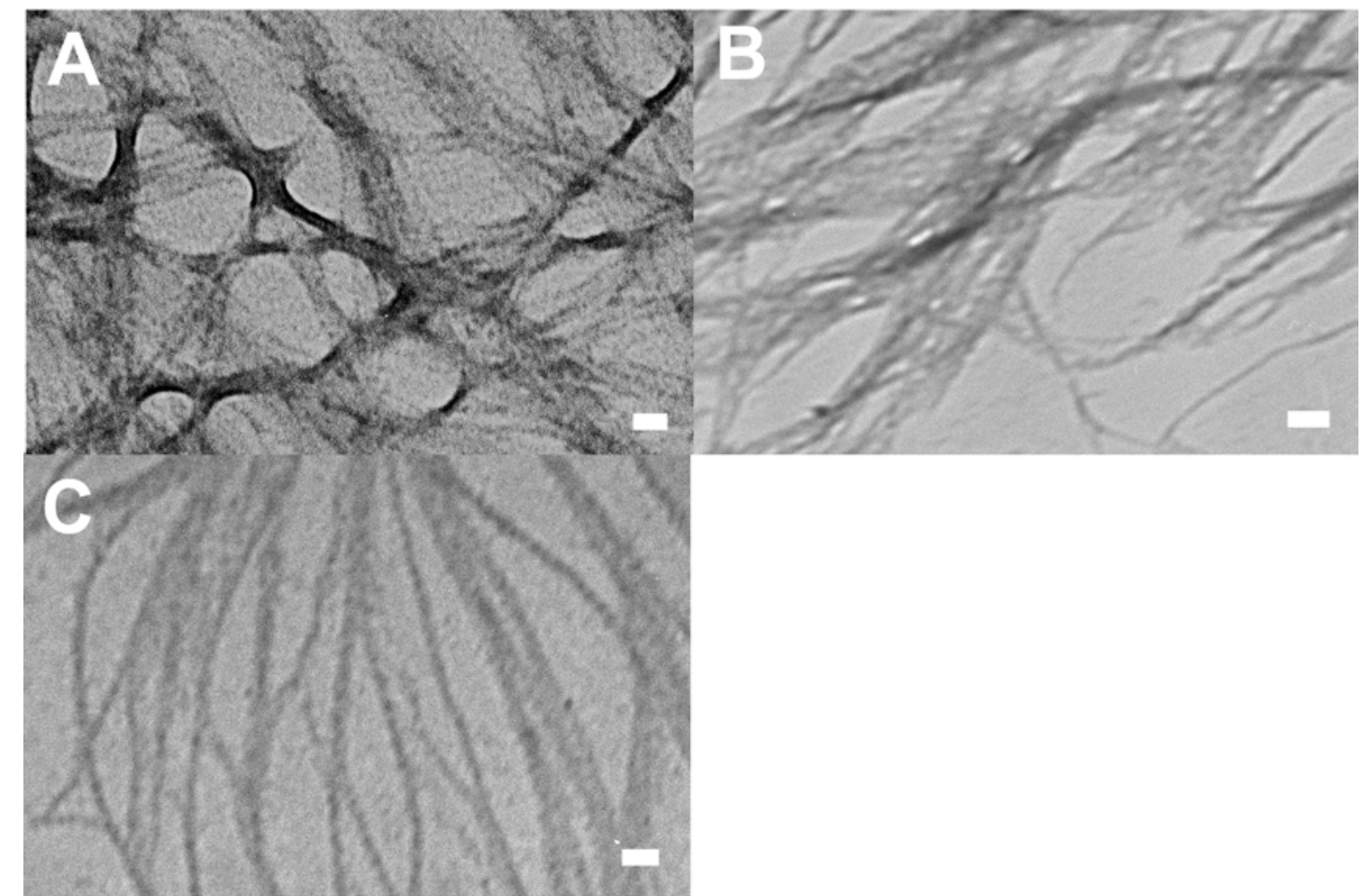

Figure 2. The TEM images of the nanofibers in the hydrogels of (A) 1, (B) 2, and (C) $\mathbf{3}$ (scale bars = $100 \mathrm{~nm})$.

Procedure to test the responses of the hydrogels to vancomycin: To the hydrogel containing $5 \mu \mathrm{mol}$ Fmoc-D-Ala-D-Ala, $5 \mu \mathrm{mol}$ of the solid of vancomycin hydrochloride salt was added. At first, the solid just distributed on the surface of the gel, then it dissolved in water matrix of the gel and the hydrogel was destroyed gradually. Total conversion from gel to solution was completed within 100 minutes. While in the case of the Fmoc-L-Ala-L-Ala hydrogel, though the vancomycin hydrochloride salt was slowly absorbed by the hydrogel, the hydrogel didn't exhibit gel-sol transition even after weeks. 